\title{
Chemical Modeling: From Paul Ehrlich's Dyes to $\beta$-Blockers-A Brief History
}

\author{
ANTHONY S. TRAVIS
}

\begin{abstract}
The synthesis on the laboratory bench of the natural product known as alizarin was achieved in 1868. The subsequent elucidation of its structure was a milestone in the development of chemical theory based on Kekule's benzene ring and in the growth of the synthetic dyestuff industry. Dye and dyeing properties and theories were exploited for biological studies by the medical researcher Paul Ehrlich. Particular attention was paid to the side chains (functional or attached groups of atoms) of molecules. They became important in visualizing a mechanism for immunity, and then in the early 1900s for enabling a description of chemotherapeutic action. These side chains were transformed into the receptors that played a vital role in the development of theories well suited to the design of drugs during the second half of the twentieth century.
\end{abstract}

Keywords: history of chemical and biological modeling, James Black, John Langley, Paul Ehrlich, Raymond Ahlquist.

$\mathbf{T}$

HE YEAR 2018 MARKS the sesquicentennial of the first synthesis on the laboratory bench of a complex, naturally occurring organic product. This product was the red dye known as alizarin, obtained from the root of the madder plant. The synthesis was achieved early in 1868 by Carl Graebe and Carl Liebermann, assistants of the chemist Adolf Baeyer in Berlin. The significance lay in the tremendous industrial importance of the natural dye. During 1869-1870, as an outcome of the synthesis, alizarin was manufactured on a vast scale in Britain and Germany, at a stroke almost wiping out much of the cultivation and trade in the madder dye. This was a scientific and technological tour de force, and the main stimulus for the emergence of the synthetic dyestuff industry based on coal tar products. It also stimulated scientific studies into the chemical constitutions and molecular structures of both natural products such as alizarin and indigo and others without analogs in nature.

In 1868, the red alizarin dye was found to be a dihydroxyanthraquinone. It was synthesized in three steps from the coal tar aromatic hydrocarbon anthracene (Fig. 1). However, at that time only a partial structure could be drawn. The elucidation of the complete structure of alizarin became a leading research topic. The modern structure, showing the location of ring substituents or side chains (attached functional atoms or groups of atoms), was published in 1874 in an article coauthored by the academic chemist Adolf Baeyer

Sidney M. Edelstein Center for the History and Philosophy of Science, Technology and Medicine, The Hebrew University of Jerusalem, Jerusalem, Israel. 


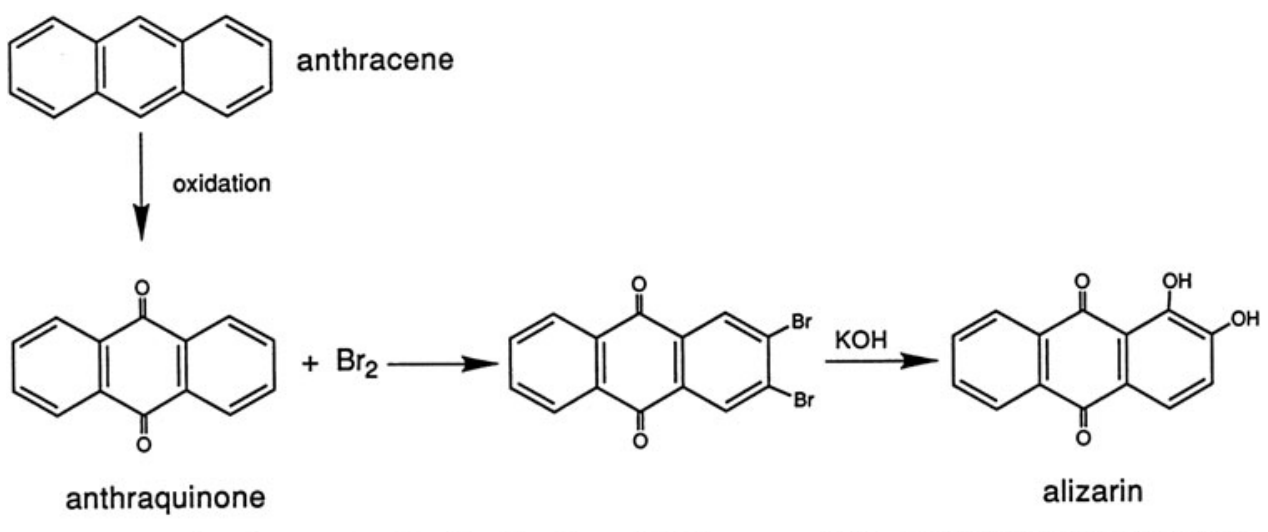

Conversion of anthracene to alizarin, Graebe and Liebermann, 1868. [modern structural formulae]

FIG. 1. The structure of alizarin as shown became available in 1874 (Baeyer and Caro). It was supported by degradation and synthesis, elemental analysis, and reaction patterns, fitting in with the then recently developed body of theoretical knowledge in aromatic organic chemistry. From: Anthony S. Travis, The Rainbow Makers: The Origins of the Synthetic Dyestuffs Industry in Western Europe (Bethlehem, PA: Lehigh University Press, 1993), p. 175.

and the industrial chemist Heinrich Caro at the dye manufacturing firm BASF of Ludwigshafen (Travis, 1993). This achievement drew on, and in many ways reinforced, the acceptance of Kekulé's six-membered benzene ring of 1865 . Through the successful application to the production of material goods, the alizarin synthesis was the main early advance in the use of theoretical concepts in aromatic organic chemistry. By extension, as described here, it was the scientific basis for visualizing a model of the surface of the biological cell, and describing the behavior of side chains, better known as receptors, on the surface of the cell (Prüll, 2003).

The structure of alizarin was established while Baeyer was at the new German University of Strasbourg (1871-1875). Baeyer relied on test tube experiments, chemical analysis, and the new methods of synthesis for structure determination. Evidence of structure followed after compounds such as alizarin were broken down (degraded) stepwise, under different reaction conditions, to obtain identifiable decomposition substances such as hydrocarbons (anthracene in the case of alizarin), also called mother substances, and then reconstructed by synthetic methods (a process called by chemists the method of total synthesis). This exercise, the degradation method and the reverse, is a classical structural determination or classical structural proof. It is like disassembling and then reassembling the building blocks. The outcome, drawing on thought experiments and the intuition of the experimenter, is essentially a strong model, a unique chemical signature, graphically represented, showing the location of every atom and atomic grouping in a target molecule. For any compound, there can be but a single correct structural formula. The unique structural formula came to serve also as a model as well as a symbol (Hoffmann and Laszlo, 1989; Cooke, 2004).

During 1873-1874, the medical student Paul Ehrlich (1854-1915) was also at Strasbourg undertaking research for his doctorate. Ehrlich had a strong interest in dyes as staining agents after observing his cousin, pathologist Carl Weigert, investigate staining of microorganisms with both natural and synthetic dyes. Biological staining became the basis of Ehrlich's thesis. For his research, he relied on Baeyer's laboratory for the supply of a wide range of novel colored compounds that were undergoing investigation (Travis, 1989). Ehrlich's tools were the microscope and the newly synthesized dyes. And his method, based on a thorough knowledge of structural interpretations and dye classification, was borrowed from well-proven studies in aromatic organic chemistry, the central scientific endeavor of chemistry.

Ehrlich was especially intrigued by a major development in theoretical and predictive studies related to the properties of dyes used in the dyeing and printing industries. This was Otto N. Witt's theory of color and constitution. Witt stated that the attached groups of atoms, the side chains, on the aromatic nucleus of the dye molecule were of two types: color fixing and color rendering, or auxochrome (haptophore) and chromophore components, respectively (Witt, 1876). Both properties were essential if the substance was to act as a textile dye. Using this model, Witt successfully predicted the existence of an unknown colorant, a yellow of the azodye $(-\mathrm{N}=\mathrm{N}-)$ type. Witt's theory and the widespread availability of azo and other synthetic dyes would become essential to Ehrlich's research agendas, particularly into cellular structure and, later, biological specificity. 
In 1878, Ehrlich completed his doctoral thesis, Beiträge zur Theorie und Praxis der histologischen Färbung, at Leipzig (Ehrlich, 1956 [1878]). He classified major dyes according to their then-known structures and described their uses as staining agents to differentiate tissues. Later in the same year, Ehrlich joined the University of Berlin's medical clinic, the Charite, where he was encouraged to continue his histological studies. Ehrlich discovered a new use for dyes, one that did not involve just staining but rather exploited the loss of color as dyes were reduced to probe the cell's affinity for oxygen. The transformation from a colored to a colorless substance, achieved by reduction to the leuco form, was in most instances reversible and in some cases applicable to the measurement of both oxidation and reduction states in living organisms.

The study of oxygen uptake in living animals, the "vital staining," became the basis of Ehrlich's 1885 Habilitation thesis, Das Sauerstoff-Bedürfniss des Organismus. Ehrlich showed that dyes are transported in the blood stream as fine particles, the form in which they enter the cells. He observed the in vivo reduction of colorants with different oxidation/reduction, or redox, potentials such that: “....it is almost self-evident that if one wishes to investigate the oxygen requirement of the protoplasm [cytoplasm], one can only do this by proxy, making use of compounds [dyes] which, in relation to oxygen, are analogous to protoplasm in their behaviour" (Ehrlich, 1956 [1885]). Using this powerful analogy, Ehrlich eliminated the complex, diverse, and unknown chemical reductions in the living cell to suggest the external appearance of the protoplasm, inspired by chemical imagery, based on aromatic chemical structures. By comparing different dyes, he even made semiquantitative measurements of oxygen uptake (Fischer et al., 2006).

Ehrlich also compared the behavior of blood serum in the organism with the action of serum when used as a thickening agent in textile printing and dyeing. Serum and other thickening agents prevented precipitation of dyes, which suggested a mode of transfer of his fine particles, the dyes, which were taken up by the blood as ultrafine suspensions.

This led Ehrlich to propose a mechanical mode of entry of dyes into the cell. Using this approach, Ehrlich established the fine structure of the boundary surface of cells based on another analogy, this time with a membrane. It became the basis of descriptive models of the form and function of the cell surface. Further support came from the observation that increasing the size of the dye, as in the case of alizarin blue $\mathrm{S}$, reduced the extent of color loss, since only larger pores were easily penetrable. With the help of samples provided by Heinrich Caro, Ehrlich used alizarin blue combined with a number of metal salts to produce insoluble double compounds (lakes), just like those prepared in the fixing process of dyes, to further demonstrate this feature of dye uptake. Ehrlich's models, such as those adopted by chemists, were visual representations that served their intended purposes. In the same way that chemists developed theories based on the intuitive approach, following extensive experimental studies involving synthesis, the nature and reactions of functional groups, and characterization, Ehrlich developed theories that extended this approach, for the first time, to the processes of life. Staining of tissues with synthetic dyes, which began around 1860, became the bridge between chemical structural modeling, based on theories developed from the mid-1860s, and biological modeling.

In 1881, Ehrlich used Caro's methylene blue dye in bacterial staining. In 1882, he introduced a differential or selective staining method for Robert Koch's newly discovered Bacillus tuberculosis (tubercle bacillus, Mycobacterium tuberculosis), based on acid-fast staining with basic dyes and methylene blue. In 1886, methylene blue was shown by Ehrlich to not only be a good stain for bacteria but also to have specificity for nerve cells, the so-called vital staining (Travis, 1991). Within a few years, new approaches to chemical theory would lead to more far-reaching applications of Ehrlich's methods to biological systems.

The graphical representation of atoms in space followed proposals for the tetrahedral carbon atom and studies on optical activity in the early 1870s by chemist Jacobus Henricus van't Hoff (1852-1911). The subsequent confirmation of the tetrahedral model for carbon was a major development. Similar results were obtained by Joseph Achille le Bel (1847-1930), whose inspiration had come from Pasteur's speculations on the different spacial arrangements of isomers. Ironically it was an attack in 1877 by the prominent chemist Hermann Kolbe on van't Hoff's theory that led to great publicity for, and eventually acceptance of, the tetrahedral model (Benfey, 1992 [1964]: 104-108). A further breakthrough in stereochemistry, emphasizing the need to visualize molecules in three dimensions, came in 1891 when Emil Fischer published projection diagrams for monosaccharides. In 1894, Fischer invoked molecular geometry to explain enzymatic hydrolysis. "To use a [mental] picture, I would say that the enzyme and glucoside must fit each other like a lock and key" (Fischer, 1894). This novel invention of the mind, the principle of complementarity, provided an image well suited to the concept of specificity and modeling applied to cellular activity. The existence of bodies that coupled smoothly to each other would contribute to an effective theoretical means 
for understanding the central problem of how the cell behaves when under the influence of products introduced into the organism.

Ehrlich drew on these several developments in chemistry to propose his Side Chain Theory (Seitenkettentheorie) of immunity (Ehrlich, 1957 [1897]; Michaelis, 1914). This happened following a change in direction caused by an unsuccessful attempt around 1890 at using dyes to attack sites of infection within the body. As a result, in 1891, Ehrlich had commenced studies into how serum therapy provided immunity against diphtheria and tetanus. Ehrlich found that anti-diphtheria antitoxin and diphtheria toxin were readily titrated, leading him to believe that they were molecules that could be treated in the same way as other chemicals. Each toxin, or antigen (a term introduced in 1903), precipitated only with its complementary antibody. Quantitative standards had now been established, enabling a unit of toxin to be defined, thereby suggesting a means for calculating remedial dosages (Ehrlich, 1957 [1897]).

Ehrlich created a new language to explain his findings and introduced the concept of the cellular side chain (a term borrowed from the chemical side chains in aromatic molecules). This provided a mechanism for describing immunity. In part, this was suggested by the fact that, unexpectedly, when toxicity was lost, the toxin remained fixed to the antibody (Silverstein, 2002; Travis, 2008).

Drawing on Witt's theory, which differentiated between the color-rendering and color-fixing functional groups, fixing power and toxicity were defined as independent properties of the antigen toxin (Mazumdar, 1974; Cambrosio et al., 1993). Now, Ehrlich, after using dyes to model cell walls as membranes that control transport into cells, adapted Witt's theory of dyeing and the organic structure theory to draw cartoons that visualized his side chain theory of immunity (Fig. 2). (The antigens were then believed to be bacteria.) The combining components, the haptophores, became attached to the side chains of protoplasm (cytoplasm) that were normally involved in digestion, or nutritive consumption. The cell responded with a process of recognition, by producing antibodies (serum proteins) with affinities to specific antigens: the antigen/ antibody interaction (specificity). To demonstrate the applicability of his model, Ehrlich included overproduction of antibodies created in response to, and activated by, the approach of the antigen. The surplus of these antitoxins was retained in the body, ready to combine with and neutralize the toxins. The toxin/ antitoxin reaction was another powerful extension by Ehrlich of chemical principles as developed into a model suited to biological studies.

By the end of the 1890s, Ehrlich's achievements were widely acknowledged. In 1900, in his Croonian Lecture, given in London, Ehrlich introduced the term poison receptor, or receptor, as an alternative to side chain for the group of atoms in the protoplasm that unite with the toxin (Ehrlich, 1957 [1900]). Through an elegant analogy, once more a complex system was made understandable, and after 1907, as described below, it was extended to drug discovery (Ehrlich, 1908a). In 1908, Ehrlich received the Nobel Prize in physiology or medicine for his work on immunity, shared with his adversary in immunity theory Ilya Ilyich Mechnikov (Ehrlich, 1967 [1908b]; Vikhanski, 2016). By this time, he had returned to attacking sites of infection within the body, that is, chemotherapy (Rupin, 1980; Parascandola, 1981).

It is important at this stage to emphasize that Ehrlich did not believe at first that his side chain theory could be adapted to the pharmacological action of drugs. As far as he was concerned, there was no chemical union, just a chemical affinity. Only in 1907 did he accept that synthetic drugs could attach to the protoplasm of the cell through receptors, or "chemoreceptors" (Ehrlich, 1909). Ehrlich owed his recognition of the role of receptors in the mechanism of drug action to the English investigator John Newport Langley (18521925). Langley championed Ehrlich's hypothesis by proposing that specific receptors bind drugs or transmitter substances onto the cell with differentiation, either initiating biological effects or inhibiting cellular functions.

Langley's ideas on the mode of action of drugs were fully developed in 1905 with the concept of "receptive substances." This model was described in the Journal of Physiology, of which he was the editor. Ehrlich's side chain theory was used to consolidate Langley's theory, and Langley proposed a receptor theory of drug action based on chemical binding, something that, as noted above, Ehrlich only accepted later.

Chemical binding of antagonistic alkaloids to cellular protoplasm had been proposed in the late 1870s by the Swiss physiologist Balthasar Luchsinger (1849-1886). This appealed to Langley as a model for the mode of interaction between alkaloids and cellular protoplasm; he later described two poisons that were bound chemically to the tissue, based on relative chemical affinities to the tissue and the mass of each one present (Maehle, 2004: 159-161).

Langley's substances were "atom-groups of the protoplasm." Two groupings of atoms had to be distinguished, the receptive and the fundamental. When chemical substances were bound to the receptive 


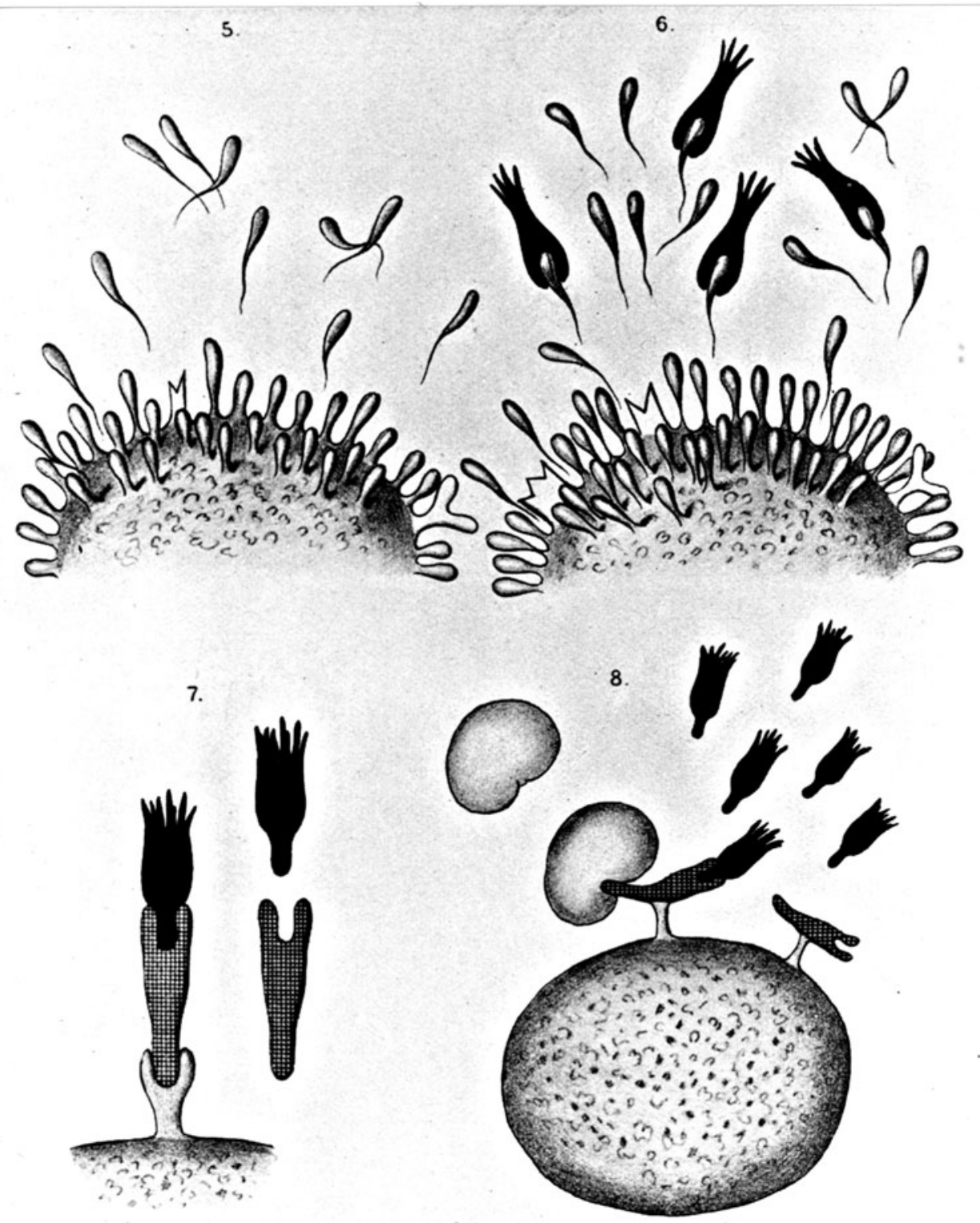

FIG. 2. Section of "cartoon," which Paul Ehrlich used to visualize his side chain theory of immunity (1897). (Edelstein Center, Hebrew University.)

group, they changed the cell's function. Langley proposed that the receptive groups were either "motor" excitatory or "inhibitory." This was based on experimental studies with adrenaline and nicotine, suggesting the existence of different adrenotropic receptors on a cell's surface.

According to Langley's theory, certain fundamental groups support cellular life. If a chemical substance became attached to these groups, they would start to die. Langley gave as an example Ehrlich's findings related to the destructive effect of arsenic compounds on trypanosomes. Subsequently, Ehrlich accepted chemical binding and introduced the theory of "chemoreceptors" that involved attachment through chemical bonds to drugs (Parascandola and Jasensky, 1974).

Ehrlich now emphasized the need to "learn to aim, aim in a chemical way" (Ehrlich, 1909). Success in chemotherapy, based on large-scale screening campaigns, was made possible by the arrival of the Japanese researcher Sahaschiro Hata, who had spent a few years in German research institutes before joining Ehrlich early in 1909. After screening several hundred products, Ehrlich and Hata found that an arsenic compound with what was believed to contain the linkage -As $=$ As-, analogous to the azo-dye linkage $-\mathrm{N}=\mathrm{N}-$ (in which 
this grouping of two nitrogen atoms is the bridge between two aromatic entities), attacked syphilis and other infections within the body. The outcome of the collaboration between Ehrlich and Hata was compound 606 (arsphenamine), the first effective drug to attack sites of infection within the body. Compound "Ehrlich-Hata 606" was manufactured by Hoechst dyeworks and made available in 1910 as Salvarsan. This was Ehrlich's “magic" bullet (Lenoir, 1988; van den Belt, 1997).

The concepts of Ehrlich and Langley, based on strong chemical models, received opposition and sometimes fierce attacks from those who favored a mode of drug action based on physical, rather than chemical, attachment (Parascandola, 1988; Maehle, 2004; Prüll et al., 2000). Langley's model found support in the work of Alfred Joseph Clark in the interwar period, and most especially through his 1933 book The Mode of Action of Drugs on Cells. Support, although to a lesser extent, also came from the studies of Henry Dale.

In industry, further progress was stimulated in the mid-1930s by the discovery at the German behemoth IG Farben of the first of the new sulfa drugs, as a result of screening campaigns on dyes using the concepts laid down by Ehrlich. This followed Gerhard Domagk's discovery of prontosil, and the finding at the Pasteur Institute that the active substance was a breakdown product whose synthesis had been described in 1908. Since it could not be patented, firms in Britain and America, drawing on their strengths in aromatic organic chemistry, particularly dye intermediates, commenced studies into pharmaceuticals. Among them was Britain's leading chemical corporation, Imperial Chemical Industries (ICI).

In 1956, a program to discover what were eventually called $\beta$-blockers started at ICI in its dedicated Pharmaceutical Division at Alderley Park in Cheshire (Quirke, 2006). There, research was undertaken into cardiovascular disease. The major development took place after July 1958 when James Whyte Black (1924-2010) joined the division from the University of Glasgow's veterinary school. Black had already worked on a method for blocking the action of adrenaline on the heart, to reduce the supply of oxygen. He was interested in an adrenoceptor-blocking drug that might be of value in treatment of heart disease, more specifically angina pectoris. Relevant here is the fact that his father had recently died following a car crash. The death was caused not by the crash, but from the stress, which caused a heart attack (Kennedy, 1986: 136). This led Black to think about how stress leads to the production of adrenaline, and the mechanism of angina and heart attacks.

Black was struck by a theory he came across in a 1954 reprint of an article originally published in 1948 by Raymond Ahlquist (1914-1983), of Des Moines, Iowa (Ahlquist, 1948). Ahlquist, not unlike Langley, defined two distinct types of adrenergic receptors, $\alpha$ and $\beta$. Ahlquist demonstrated that the binding of catecholamine and other sympathomimetic drugs to $\alpha$ receptors led to excitatory responses, while binding to $\beta$ receptors produced inhibitory responses (Quirke, 2006). Ahlquist's theory, as Black explained, "was that a cell responded to different substances because of the decoding machinery it had on its receptors. Ahlquist called them alpha and beta. They behaved as if they were different and he was the only one who uniquely saw that" (quoted in Kennedy, 1986: 137). This dual-receptor theory had been rejected by the editor of the Journal of Pharmacology and Experimental Therapeutics but was accepted for publication in 1948 by the American Journal of Physiology. It was then mainly ignored, in part, due to the acceptance still given to Walter Bradford Cannon's 1930s theory that described the chemically unidentified sympathins E and I as, respectively, excitatory and inhibitory mediators of adrenergic nerve impulses.

The ICI study received a major impetus following the independent discovery at Eli Lilly Laboratories that the compound DCI (dichloro isoprenaline) cut back the effect of adrenaline. In 1957, Neil C. Moran at Emory University, Atlanta, asked for samples and confirmed the beneficial effect of DCI. In 1958, Powell and Slater described DCI's pharmacological properties (Powell and Slater, 1958). In Black's opinion this "provided the turning point and [brought about] the rapid acceptance of the idea of a dual-receptor mechanism," in other words, the dual-receptor theory (Black, 1976: 12). Moran and Marjorie E. Perkins argued that DCI belonged to Ahlquist's $\beta$-adrenergic type. From this they coined the term $\beta$-adrenergic blocking drug (later $\beta$-blocker; Moran and Perkins, 1961). Black, drawing on Moran's report in which DCI increased the heart rate through binding to the $\beta$-receptor, sought out an alternative product that might exhibit the blocking action of cardiac effects of the sympathetic nervous system.

The breakthrough came in January 1960 after John Stephenson, a medicinal chemist at ICI's Alderley Park, replaced two chlorines in DCI with a phenyl to make a naphthalene compound. It exhibited enhanced inhibitory activity. The new compound, pronethalol, became a prototype for the product that Black was seeking out (Black and Stephenson, 1962). During clinical trials in 1962, it usefully blocked cardiac effects of the sympathetic nervous system, although there were side effects, and it was never used clinically. 
However, renamed Alderlin (from Alderley), and also Netherlide, it represented a major step forward in the search for a drug that would, hopefully, selectively block the adrenoceptor function. It was followed by the more effective propranolol, which underwent clinical trials in 1964; it effectively blocked the effect of the stress hormones adrenaline and its relative norepinephrine. This first commercially successful $\beta$-blocker ( $\beta$ adrenergic antagonist), brand name Inderal, became available in July 1965 (Reuben and Wittcoff, 1989: 202207). The only serious rival was sotalol, which was originally synthesized in 1960 at Mead Johnson, and 4 years later at ICI, where its acetamido derivative practolol (Eraldin) was introduced in 1970, although not without side effects, including deaths, in some cases (Eraldin was withdrawn in 1975; Quirke, 2006). After ICI refused to allow James Black to work on similar targeted drugs for stomach ulcers, he moved to Smith Kline French, where in the late 1960s he developed cimetidine (brand name Tagamet, etc.), the first $\mathrm{H}_{2}$-blocker for stomach acidity (Reuben and Wittcoff, 1989: 284-289). It became the largest selling prescription drug. Black was knighted in 1986 and received the Nobel Prize in physiology or medicine in 1988.

In the 1970s, the first receptors were isolated as specific proteins of the cell membrane, leading to extensive studies of composition and conformation. This was particularly important for modeling, enabling the receptor concept to drive theories of drug discovery and structure-activity relationship studies for drug development. The concept's origins, as shown in the foregoing, are found in the studies of John Langley, Raymond Ahlquist, Neil Moran, James Black, and investigators in industrial laboratories. Their models were inspired by those of Paul Ehrlich, who started out by using commercial synthetic dyes as his tools. His concepts and theories were an early and important contribution toward modern modeling in biology (Van Regenmortel, 1998; Laubichler and Müller, 2007).

\section{CONCLUSION}

This article has shown how a novel approach to biological problem solving was based on industrial products and theories of organic chemistry. The success of alizarin led to developments in chemical theory and the availability of a wide range of synthetic dyes and intermediates. Paul Ehrlich, after using these dyes to model cell walls as membranes that control transport into cells, adapted Witt's theory of dyeing and the organic structure theory to establish his side chain, or receptor, theory of immunity. Ehrlich's side chains fixed bacterial toxins to cellular tissue. His model provided an explanation for how, once formed in excess, antitoxins (antibodies) depart from the cell and circulate in the blood.

Ehrlich moved smoothly through staining, organic structural chemistry, a theory of dyeing, cell structure, immunology, immunochemistry, and chemotherapy, drawing at all times on a major technological system, synthetic dye chemistry. Dyes were ideal molecular probes. His assumptions were borne out in practice. Studies with synthetic dyes and new chemical concepts embedded his sensory experience into a cartoonlike representation of the cell that became a model for attacking sites of infection within the body. Paul Ehrlich's legacies are a theory of immunity and "the magic bullet," the specific chemical "receptor" that fixes drugs or transmitter substances to cells (Travis, 2008). Contributors toward progress included John Langley, who favored chemical bonding to receptors and also postulated the existence of two types of specific cellular receptors, each with a different function.

Following academic and industrial interest, the success of receptor-subtype-specific drugs, notably the $\beta$-adrenergic receptor antagonist propranolol, in the 1960s led to major advances in drug design. In the same period, James Black at ICI Pharmaceuticals explored the idea of blocking specific biochemical pathways in the body to cure diseases. He developed the first of the $\beta$-blockers for high blood pressure and heart diseases, and later became involved in the development of cimetidine. These new drugs were very successful in both medical and economic terms, and became known as blockbusters. They eventually led certain sectors of the chemical industry, including divisions previously engaged in dye production, to move over almost completely to pharmaceuticals.

\section{ACKNOWLEDGMENTS}

I thank an anonymous referee for suggesting a number of corrections and amendments to an earlier version of this article. Members of staff at the Edelstein Library, The National Library of Israel, and the Wellcome Institute, London, are thanked for the great assistance rendered at all times. 


\section{AUTHOR DISCLOSURE STATEMENT}

The author declares there are no competing financial interests.

\section{REFERENCES}

Ahlquist, R.P. 1948. A study of the adrenotropic receptors. Am. J. Physiol. 153, 586-589.

Benfey, O.T. 1992 [1964]. From Vital Force to Structural Formulas. Beckman Center for the History of Chemistry, Philadelphia.

Black, J.W. 1976. Ahlquist and the development of beta-adrenoceptor antagonists, 11-13. In Hoffbrand, B.I., Shanks, R.G., and Brick, J., eds. Ten Years of Propranolol: A Symposium on the History and Future of Beta-Blockade (Amsterdam, September 26-28, 1975). Postgraduate Medical Journal, 52(Suppl. 4).

Black, J.W., and Stephenson, J.S. 1962. Pharmacology of a new adrenergic beta-receptor-blocking compound, Nethalide. Lancet. 2, 311-314.

Cambrosio, A., Jacobi, D., and Keating, P. 1993. Ehrlich's "beautiful pictures" and the controversial beginnings of immunological imagery. Isis. 84, 662-699.

Cooke, H. 2004. A historical study of structures for communication of organic chemistry information prior to 1950. Org. Biomol. Chem. 2, 3179-3191.

Ehrlich, P. 1956 [1878]. Contributions to the theory and practice of histological staining. 65-98.

Ehrlich, P. 1956 [1885]. The requirement of the organism for oxygen: An analytical study with the aid of dyes. $433-$ 496.

Ehrlich, P. 1957 [1897]. The assay of the activity of diphtheria-curative serum and its theoretical basis. 107-125.

Ehrlich, P. 1957 [1900]. On immunity with special reference to cell life. 178-195.

Ehrlich, P. 1908a. Experimental Researches on Specific Therapeutics [The Harben Lectures for 1907]. Royal Institute of Public Health/Lewis, London.

Ehrlich, P. (1967) [1908b]. Partial cell function [Nobel Lecture, December 11, 1908], 304-320. In Nobel Lectures. Physiology or Medicine 1901-1921. Elsevier, Amsterdam.

Ehrlich, P. 1909. Über den jetzigen Stand der Chemotherapie. Ber. Dtsch. Chem. Ges. 42, 17-32.

Ehrlich, P. 1956, 1957. The Collected Papers of Paul Ehrlich, Volume 1, Histology, Biochemistry and Pathology (1956); Volume 2, Immunology and Cancer Research (1957). Himmelweit, F., Marquardt, M., and Dale, H.H., eds. Pergamon, London.

Fischer, E. 1894. Einfluss der Configuration auf die Wirkung der Enzyme. Ber. Dtsch. Chem. Ges. 27, $2985-2993$.

Fischer, T., Dunker, T.H., and Steinmetzer, J. 2006. "Erkenntnisse durch "Schönfarberie"? Uber farbe als Indikator des Unsichtbaren und Übersetzer von Zellfunktion am Beispiel von Paul Ehrlich," 63-75. In Gross, D., and Dunker, T.H., eds. Farbe-Erkenntnis-Wissenschaft. Zur epistemischen Bedeutung von farbe in der Medizin, LIT Verlag, Münster.

Hoffmann, R., and Laszlo, P. 1989. Representations in chemistry. Diogenes. 37, 23-51.

Kennedy, C. 1986. ICI: The Company That Changed Our Lives. Hutchinson, London.

Laubichler, M., and Müller, G.B., eds. 2007. Modeling Biology: Structures, Behaviors, Evolution. MIT Press, Cambridge, MA.

Lenoir, T. 1988. A magic bullet: Research for profit and the growth of knowledge in Germany around 1900. Minerva. 26, 66-88.

Maehle, A.-H. 2004. "Receptive substances": John Newport Langley (1852-1925) and his path to a receptor theory of drug action. Med. Hist. 48, 153-174.

Mazumdar, P.H. 1974. The antigen-antibody reaction and the physics and chemistry of life. Bull. Hist. Med. 48, 1-21.

Michaelis, L. 1914. Die Bedeutung der Farbstoff für Ehrlichs biologische Forschungen. Die Naturwissenschaften. 2, 250-251.

Moran, N.C., and Perkins, M.E. 1961. An evaluation of the adrenergic blockade of the mammalian heart. J. Pharmacol. Exp. Ther. 133, 192-201.

Parascandola, J. 1981. The theoretical basis of Paul Ehrlich's chemotherapy. J. Hist. Med. 36, 19-43.

Parascandola, J. 1988. Form and function: Early efforts to relate chemical structure and pharmacological activity. Can. Bull. Med. Hist. 5, 61-72.

Parascandola, J., and Jasensky, R. 1974. Origins of the receptor theory of drug action. Bull. Hist. Med. 48, 199-220.

Powell, C.E., and Slater, I.H. 1958. Blocking of inhibitory adrenergic receptors by a dichloro analog of isoproterenol. $J$ Pharmacol. Exper. Ther. 122, 480-488.

Prüll, C.-R., Maehle, A.-H., and Haliwell, R.F. 2009. A Short History of the Drug Receptor Concept. PalgraveMacmillan, London. 
Prüll, C.-R. 2003. Part of a scientific master plan? Paul Ehrlich and the origins of his receptor concept. Med. Hist. 47, 332-356.

Quirke, V. 2006. Putting theory into practice: James Black, receptor theory and the development of the beta-blockers at ICI, 1958-1978. Med. Hist. 50, 69-92.

Reuben, B.G., and Wittcoff, H.A. 1989. Pharmaceutical Chemicals in Perspective. John Wiley \& Sons, New York.

Rupin, L.P. 1980. Styles in scientific explanation: Paul Ehrlich and Svante Arrhenius on immunochemistry. J. Hist. Med Allied Sci. 35, 397-425.

Silverstein, A.M. 2002. Paul Ehrlich's Receptor Immunology: The Magnificent Obsession. Academic Press, San Diego.

Travis, A.S. 1989. Science as receptor of technology: Paul Ehrlich and the synthetic dyestuffs industry. Sci. Context. 3, 383-408.

Travis, A.S. 1991. Paul Ehrlich: A hundred years of chemotherapy, 1891-1991. Biochemist. 13, 9-12.

Travis, A.S. 1993. The Rainbow Makers: The Origins of the Synthetic Dyestuffs Industry in Western Europe. Lehigh University Press, Bethlehem, PA.

Travis, A.S. 2008. Models for biomedical research: The theory and practice of Paul Ehrlich. Hist. Philos. Life Sci. 30, 79-98.

van den Belt, H. 1997. Spirochaetes, serology, and Salvarsan [Ph.D. dissertation]. Landbouwuniversiteit Wageningen, The Netherlands.

Van Regenmortel, M.H.V. 1998. From absolute to exquisite specificity: Reflections on the fuzzy nature of species, specificity and antigenic sites. J. Immunol. Methods. 26, 37-48.

Vikhanski, L. 2016. Immunity: How Elie Metchnikoff Changed the Course of Modern Medicine. Chicago Review Press, Chicago, IL.

Witt, O.N. 1876. Zur Kentiss des Baues und der Bildung färbender Kohlenstoffverbindungen. Ber. Dtsch. Chem. Ges. 8, 522-527.

Address correspondence to:

Dr. Anthony S. Travis

Sidney M. Edelstein Center for the History and Philosophy of Science

Technology and Medicine

The Hebrew University of Jerusalem

Edmond J. Safra Campus

Givat Ram, Jerusalem 91904

Israel

E-mail: tony.travis282@gmail.com; travis@cc.huji.ac.il 